\title{
Gerak dan Lagu Neurokinestetik (GELATIK) untuk Menumbuhkan Kreativitas Seni Anak Usia Dini
}

\author{
Swantyka Ilham Prahesti ${ }^{\varpi_{1}}$, Nufitriani Kartika Dewi ${ }^{2}$ \\ Program Studi Pendidikan Guru Pendidikan Anak Usia Dini, Universitas Ngudi Waluyo \\ DOI: $10.31004 /$ obsesi.v4i1.289
}

\begin{abstract}
Abstrak
Tujuan penelitian ini yaitu menentukan perbedaan hasil pencapaian gerak dan lagu neurokinestetik untuk menumbuhkan kreativitas seni anak usia dini menggunakan video gelatik dan video konvensional. Desain penelitian eksperimen yang digunakan adalah nonequevalen control group design. Berdasarkan hasil penelitian dan pembahasan yang dilakukan tentang penggunaan video gerak dan lagu neurokinestetik untuk menumbuhkan kreativitas anak usia dini, maka dapat ditarik kesimpulan bahwa hasil pencapaian gerak dan lagu neurokinestetik untuk menumbuhkan kreativitas anak usia dini lebih besar dari pada hasil pencapaian gerak dan lagu neurokinestetik untuk menumbuhkan kreativitas anak usia dini menggunakan video konvensional dibuktikan melalui uji t Independent bahwa data postes antara kelompok 1 dan kelompok 2 adalah $\mathrm{H}_{0}$ ditolak karena memiliki nilai thitung $=$ 9,863 dengan $t_{\text {tabel }}=-2,048$. Penelitian yang dilakukan ini tidak hanya meneliti mengenai gerak dan lagu nya saja akan tetapi memberikan tambahan variabel yaitu menggunakan variabel Neurokinestetik yang menjadi kebaharuan dari penelitian ini. Saran dalam penelitian ini yaitu dilakukannya penelitian lanjutan tentang video gelatik dengan menggunakan tema yang lain.
\end{abstract}

Kata Kunci: anak usia dini; gerak dan lagu; neurokinestetik; video

\begin{abstract}
The purpose of this study is to determine differences in the results of the achievement of neurokinesthetic motion and songs to foster the creativity of early childhood art using conventional video and video. The experimental research design used was nonequevalent control group design. Based on the results of research and discussions conducted about the use of motion video and neurokinesthetic songs to foster early childhood creativity, it can be concluded that the results of the achievement of neurokinestetic motion and songs to foster early childhood creativity are greater than the results of the achievement of motion and neurokinesthetic songs to foster Early childhood creativity using conventional video is proven through the Independent $t$ test that the posttest data between group 1 and group 2 is $\mathrm{H} 0$ rejected because it has a tcount $=9.863$ with a table $=-2.048$. This research does not only examine the motion and song, but also provides additional variables using the Neurokinestetik variable which is the novelty of this research. Suggestion in this research is to do further research on video with using other themes.
\end{abstract}

Keywords: early childhood; motion and song; neurokinestetik; video

Copyright (c) 2019 Swantyka Ilham Prahesti, Nufitriani Kartika Dewi

$\triangle$ Corresponding author:

Email Address : swantyka05@gmail.com (Jl. Diponegoro 186 Ungaran Barat, Kab. Semarang)

Received 10 September 2019, Accepted 5 October 2019, Published 31 October 2019 


\section{PENDAHULUAN}

Tujuan pendidikan pada umumnya ialah menyediakan lingkungan yang memungkinkan anak didik untuk mengembangkan bakat dan kemampuannya secara optimal, sehingga ia dapat mewujudkan dirinya dan berfungsi sepenuhnya, sesuai dengan kebutuhan pribadinya dan kebutuhan masyarakat. Setiap orang mempunyai bakat dan kemampuan yang berbeda-beda pula. Kondisi yang ada di setiap lembaga dalam menumbuhkan kreativitas seni anak selalu berbeda-beda, akan tetapi bisa dilihat tiap lembaga hanya memberikan stimulus melalui menari, menggambar, dan berceita.

Pendidikan anak usia dini memegang peranan penting terhadap perkembangan anak karena merupakan pondasi awal dalam kepribadian anak. Anak yang berusia 4-6 tahun memiliki masa perkembangan kecerdasan yang sangat pesat sehingga masa tersebut di sebut masa keemasan (golden age). Pada masa ini, anak-anak mengalami masa peka atau masa sensitif dalam menerima berbagai upaya pengembangan seluruh potensi yang dimilikinya. Perkembangan fisik merupakan hal yang menjadi dasar bagi kemajuan perkembangan berikutnya pada anak (Susanto, 2012).

Masa peka merupakan masa terjadinya pematangan fungsi-fungsi fisik dan psikis yang siap merespon rangsangan yang diberikan oleh lingkungan. Hal ini dinyatakan pula oleh Piere Duquet (dalam Jasni, 2008:23) bahwa pada rentang usia lahir sampai enam tahun, anak mulai peka untuk menerima berbagai upaya perkembangan potensi yang dimilikinya. Menurut Nurliana Syarifah (2016) mengatakan sebagai orang tua modern, sangat mengutamakan perkembangan intelektual dari pada pengembangan kemampuan fisik. Husnul (2011), mengatakan ada beberapa manfaat yang anak peroleh setelah melakukan senam irama. 1) Meningkatkan kelentukan, keseimbangan, koordinasi, kelincahan, daya tahan, dan sanggup melakukan kegiatan-kegiatan atau olahraga lainnya. 2) Dapat membakar lemak yang berlebihan, meningkatkan daya tahan jantung dan paru-paru. 3) Senam irama merupakan salah satu jenis senam yang dapat digunakan untuk program penurunan berat badan. 4) Jika berlatih dengan ringan akan meningkatkan nafsu makan, dan jika berlatih dengan berat akan menekan rasa lapar karena banyak darah yang beredar di daerah otot yang aktif dan bukan di daerah perut. 5) Setelah melakukan senam irama, tubuh sehat dan hati riang karena pengaruh alunan musik. Seperti berlari, menari, membangun sesuatu, melakukan kegiatan seni dan hasta karya (Sujiono, 2010)

Gerak dan lagu merupakan pembelajaran di mana anak diberikan materi pembelajaran melalui gerak dan lagu. Menurut Jalal (2002) Gerak dan lagu yang dipakai dapat berupa lagu dengan tariannya, misalnya lagu bebek anak diajak untuk bergerak sesuai gerakan. Akan tetapi, gerak dan lagu ini diberikan untuk mempermudah anak dalam menerima pembelajaran dan mengembangkan kecerdasan kinestetik anak. Husnul (2011), mengatakan ada beberapa manfaat yang anak peroleh setelah melakukan senam irama. 1) Meningkatkan kelentukan, keseimbangan, koordinasi, kelincahan, daya tahan, dan sanggup melakukan kegiatan-kegiatan atau olahraga lainnya. 2) Dapat membakar lemak yang berlebihan, meningkatkan daya tahan jantung dan paru-paru. 3) Senam irama merupakan salah satu jenis senam yang dapat digunakan untuk program penurunan berat badan. 4) Jika berlatih dengan ringan akan meningkatkan nafsu makan, dan jika berlatih dengan berat akan menekan rasa lapar karena banyak darah yang beredar di daerah otot yang aktif dan bukan di daerah perut. 5) Setelah melakukan senam irama, tubuh sehat dan hati riang karena pengaruh alunan musik. Seperti yang dipaparkan oleh Yustisia (2013) ada beberapa cara dalam mengembangkan kecerdasan kinestetik yang dimiliki oleh anak usia dini: 1) meningkatkan kreativitas kita dalam melakukan permainan yang berhubungan dengan keterampilan fisik bersama buah hati; 2) tidak menolak ajakan anak untuk berolahraga bersama; 3) mengajarkan membuat berbagai kerajinan tangan; 4) memberikan kebebasan pada anak untuk bergerak; 5) mengarahkan anak pada aktivitas fisik untuk mengembangkan bakatnya. Sedangkan menurut Peter H. Werner (dalam Muhajir, 2007) senam adalah latihan tubuh pada lantai atau pada alat yang dirancang untuk meningkatkan 
daya tahan, kekuatan, kelenturan, kelincahan, koordinasi serta kontrol tubuh. Pembelajaran gerak dan lagu adalah kegiatan belajar bernyanyi sambil bergerak sesuai dengan irama musik yang dapat melatih anak dalam menerima rangsangan (Sudjono, Elisabeth T.K., \& Kusumastuti, Eny., 2017). Peningkatan kemampuan gerak sejalan dengan meningkatnya kemampuan koordinasi mata, tangan, kaki, dan kepala (Munawaroh, L \& Khotimah, N., 2018). Lokomotor, otot besar, dan aktivitas kebugaran dapat dengan mudah dikombinasikan dengan gerakan kreatif dan kegiatan musik (Jackman, 2009).

Menurut Diana, dkk (2013) Gerak dan lagu dalam pelaksanaan pembelajaran dapat dipadukan dengan bidang-bidang lain, dengan kata lain bahwa konsep pembelajaran gerak dan lagu merupakan kegiatan yang sangat mudah untuk diterapkan, simple, bisa mengembangkan aspek pembelajaran serta mengembangkan kemampuan atau kecerdasan kinestetik anak.

Sedangkan menurut Purwanti (2014) Pembelajaran gerak dan lagu pada anak usia dini sangat bermanfaat untuk merangsang perkembangan anak, khususnya perkembangan fisik dan motorik anak. Selain itu, pembelajaran gerak dan lagu juga mengembangakan 6 aspek perkembangan kemampuan anak yaitu nilai dan moral agama, fisik, sosial, dan emosional, bahasa kognitif, serta seni. Melalui pembelajaran gerak dan lagu, diharapkan dapat menjadikan anak usia dini sebagai penerus bangsa yang lincah, berbakat, kreatif, dan bersahaja. Pembelajaran gerak dan lagu biasanya menimbulkan kesan bermakna bagi anak, anak akan melebih mudah mengingat materi pembelajaran yang diberikan oleh guru. Gutawa (2002) Kebermaknaan pembelajaran gerak dan lagu akan memberikan dampak positif yaitu mengembangkan kecerdasan kinestetik tubuh anak. Musik ataupun lagu dapat digunakan sebagai sarana dalam sebuah proses pembelajaran yang efektif untuk anak-anak (Rasyid, 2010)

Menurut Busthomi (2012) terdapat beberapa cara untuk mengembangkan kecerdasan kinestetik seperti ikutsertakan anak dalam kegiatan-kegiatan terstruktur, misalnya les menari atau klub olahraga, minta anak berpartisipasi dalam aktivitas yang berorientasi pada gerakan seperti senam, balet, drama, dan olahraga. Fleetham (2006:19) menyatakan, "Intelligence is your ability to do things that other people value. It's the origin of your skills and talents". Pendapat Fleetham, bisa kita maknai bahwa kecerdasan adalah sebuah kegiatan atau sebuah kemampuan untuk melakukan hal-hal yang bernilai bagi orang lain. Pendapat dari Musfiroh (dalam Nurliana Syarifah, 2016) menyatakan bahwa: Kecerdasan kinestetik merupakan kemampuan menggunakan gerak seluruh tubuh untuk mengekspresikan ide dan perasannya serta keterampilan mempergunakan tangan untuk mencipta atau mengubah sesuatu. Sejalan dengan hal tersebut Lwin, Khoo, Lyen, \& Sim (2008) mengatakan bahwa pentingnya kecerdasan kinestetik memiliki alasan sebagai berikut membantu anak berkembang dalam aktivitas cerdas-tubuh, meningkatkan kemampuan psikomotor, meningkatkan keterampilan sosial, membangun rasa percaya diri dan harga diri, meletakkan fondasi pada gaya hidup sporty, dan meningkatkan kesehatan. Gallahue (dalam Samsudin, 2008) menyatakan bahwa untuk mengembangkan pola-pola gerak anak sebaiknya dilakukan melalui aktivitas-aktivitas menari, permainan, olahraga, dan senam, aktivitas-aktivitas tersebut masuk dalam wilayah pendidikan jasmani. Banyak manfaat yang dapat diperoleh anak ketika ia mulai terampil dalam menguasai gerakan yakni badan akan semakin sehat, lebih mandiri, percaya diri, serta sosial emosionalnya juga akan berkembang dengan baik (Saputra, 2005). Sedangkan menurut Sari (2014) kecerdasan kinestetik sangat mempengaruhi perkembangan motorik anak.

Berdasarkan penelitian yang dilakukan oleh (Umami, dkk 2016) menyatakan bahwa kinestetik adalah kemampuan menggunakan seluruh tubuh untuk mengekspresikan ide dan perasaan dengan baik dalam menangani atau menciptakan sesuatu. Pendapat lain menurut hasil dari penelitian (Majidah, 2018) bahwa kecerdasan kinestetik merupakan kemampuan menggunakan seluruh tubuh untuk mengekspresikan ide dan perasaan. Sedangkan menurut (Apit, 2012) Kecerdasan kinestetik dapat mempengaruhi perkembangan motorik berbeda 
dari setiap individu, ada orang yang perkembangan motoriknya sangat baik, seperti para atlit yang mempunyaikemampuan lebih dalam berolahraga, tetapi juga terdapat pelukis yang dapat memainkan kuas diatas kanvas karena kemampuan motorik halusnya yang demikian baik. Berdasarkan penelitian lain dari (Khasanah, 2016) bahwa anak dengan kecerdasan gerak tubuh memiliki kemampuan koordinasi yang tinggi, taktik dan senang menyentuh segala sesuatu. Sedangkan menurut (Anggraini, 2015) bahwa potensi kecerdasan kinestetik anak hanya akan terpendam apabila tidak dijadikan kemampuan melalui serangkaian stimulasi dan tidak akan menjadi prestasi tanpa adanya latihan dan disiplin. Selain itu menurut pembinaan yang dilakukann pada pendidikan anak usia dini diharapkann mampu untuk memberikan bekal dan kesiapan kepada anak dalam menempuh pendidikan pada jenjang selanjutnya (Lastari. A. A, Gading. I. K, 2016)

Menurut (Triana, 2012) kecerdasan kinestetik adalah kemampuan seseorang untuk mengolah tubuh secara ahli, atau untuk mengekspresikan gagasan dan emosi melalui gerakan, hal ini termasuk kemampuan untuk menangani benda secara cekatan atau membuat sesuatu. Sedangkan menurut (Meitarini, 2019) kecerdasan kinestetik adalah kemampuan dalam menggunakan keseluruhan potensi tubuh untuk mengekspresikan ideide dan perasaan dan memiliki kemampuan untuk menggunakan tangan untuk memproduksikan atau mentransformasikan benda. Pendapat lain dari (Respati, R \& Nur L, 2018) setiap kecerdasan tersebut akan dimiliki anak meskipun ada beberapa kecerdasan yang menonjol dan akan menjadi jati diri anak.

Dengan demikian dari pendapat-pendapat diatas dapat disimpulkan bahwa kegiatan gerak dan lagu sangat melekat erat dan tidak dapat dipisahkan terutama dalam memberikan pembelajaran kepada anak usia dini. Penelitian yang dilakukan ini tidak hanya meneliti mengenai gerak dan lagu nya saja akan tetapi memberikan tambahan variabel yaitu menggunakan variabel Neurokinestetik. Pada penelitian-penelitian yang dilakukan sebelumnya hanya fokus dengan gerak dan lagunya saja tanpa melihat tiap gerakannya. Sedangkan

\section{METODOLOGI}

Pendekatan dalam penelitian yang digunakan menggunakan pendekatan kuantitatif, dimana dalam pendekatan kuantitatif ini menggunakan data numeric dan pengolahan data. Dalam hal ini yang diujikan adalah gelatik anak usia dini. Berikut Diagram Alir Penelitian:

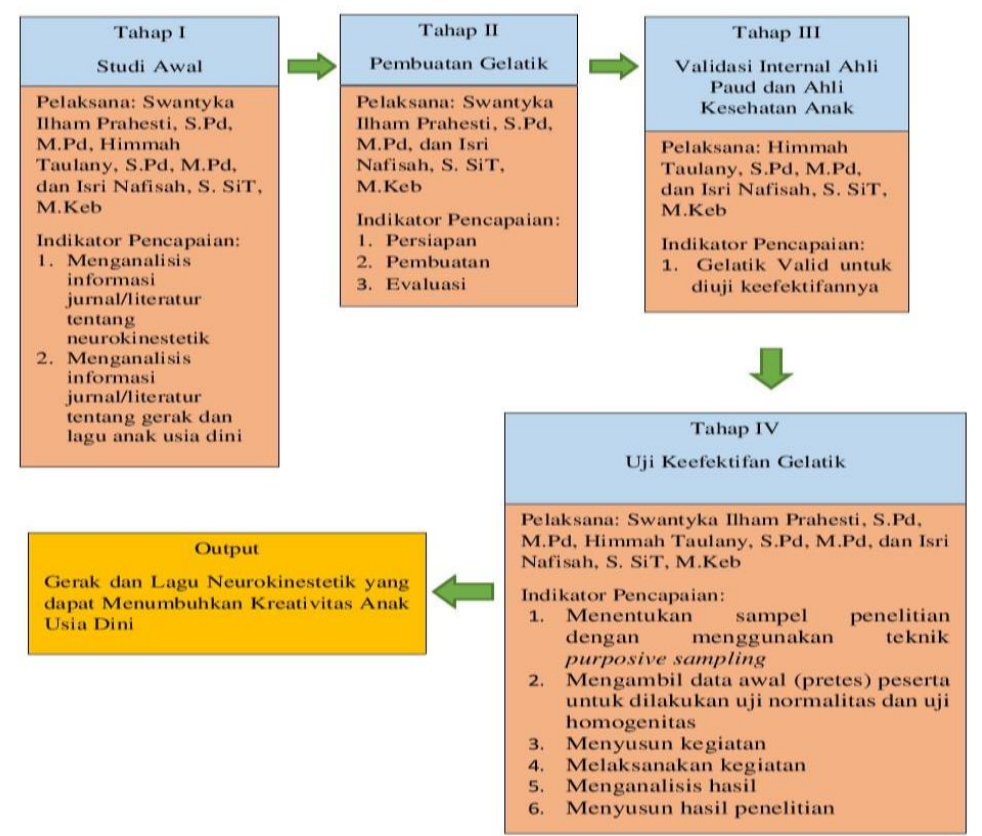

Gambar 1. Diagram Alir Penelitian 
Berikut adalah penjelasan yang ada di dalam diagram alur penelitian:

Tahap 1 Studi Awal

Kegiatan yang dilakukan yaitu menganalisis informasi jurnal/literatur mengenai neurokinetetik, gerak dan lagu

Tahap 2 Pembuatan Gelatik

Kegiatan yang dilakukan adalah persiapan, pembuatan, dan evaluasi

Tahap 3 Validasi Ahli

Kegiatan yang dilakukan adalah validasi hasil pembuatan video gelatik untuk dapat di uji keefektifannya

Tahap 4 Uji Keefektifan

Kegiatan yang dilakukan adalah menentukan sampel, mengambil data awal (pretes), menyusun kegiatan, menyusun kegiatan, melaksanakan kegiatan, menganalisis hasil, dan yang terakhir dari kegiatan ini adalah menyusun hasil penelitian

Tahap 5 Output yang dihasilkan

\section{HASIL DAN PEMBAHASAN}

Penelitian Gerak dan Lagu Neurokinestetik (GELATIK) untuk menumbuhkan kreativitas Anak Usia Dini meliputi beberapa tahapan yaitu:

\section{Studi Pendahuluan}

Dalam penelitian ini memerlukan studi pendahuluan yang berupa literatur, buku media pembelajaran dan online, untuk menentukan gerak dan lagu.

\section{Tahapan Pembuatan Video}

Dalam pembuatan video gerak dan lagu tim peneliti menciptakan gerak dan lagu yang dapat di ikuti anak usia dini dengan mudah. Berikut tahap-tahap pembuatan video gerak dan lagu neurokinestetik:

\section{Menciptakan syair}

\section{MENIRU GERAKAN BINATANG}

Mari kawan-kawan kita bermain

Meniru gerakan binatang Pastikan hati senang Pastikan hati riang

Ayo mulai dari sekarang

Lihatlah lihatlah kelinci

Melompat kesana kemari

Dengan membawa wortel

Makanan kesukaan

Pak tani mengejar menakutinya

Kelinci dor dor dor $4 x$

Lihat si monyet tertawa geli

Melihat kelinci berlari

Di silangkan tangannya dan di pegang hidungnya

Bergantian pegang telinga

Ha ha ha Hi hi hi $4 x$

Lihatlah simpanse sedang berjalan

Dengan tangan di kepala dan di perutnya 
Di tepuk dan di putarnya tangan bergantian

Oh ternyata dia menahan lapar

Uuu aaa Uuu aaa $4 x$

Kwak Kwak

Dengarlah si beo sedang berhitung

Dengan suara nyaring terdengar merdu

Satu dua satu dua $4 x$

Selesai Prok prok

\section{Membuat aransemen lagu}

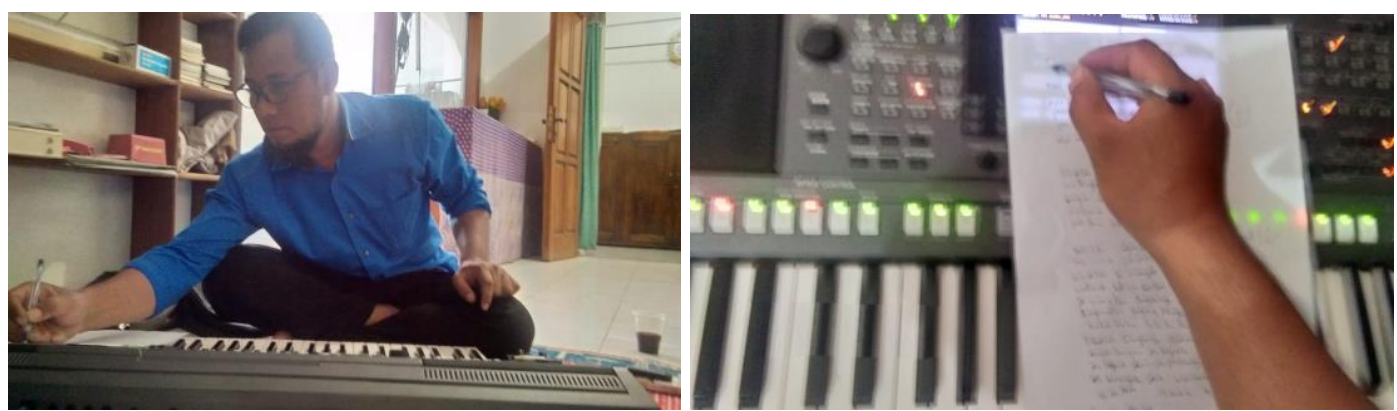

Gambar 1. Pembuatan Aransemen

\section{Proses recording}
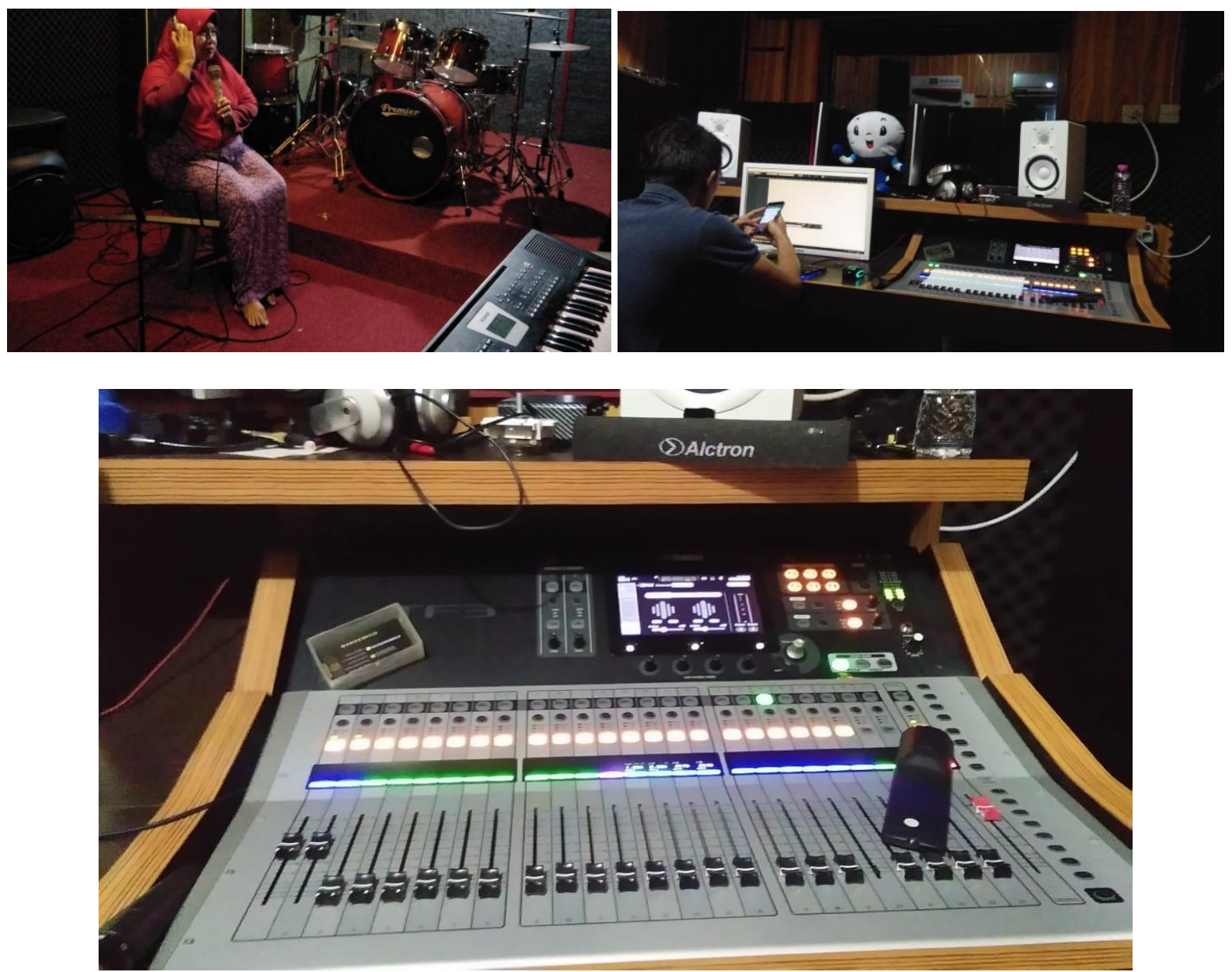

Gambar 2. Proses Recording 


\section{Menciptakan Gerakan}

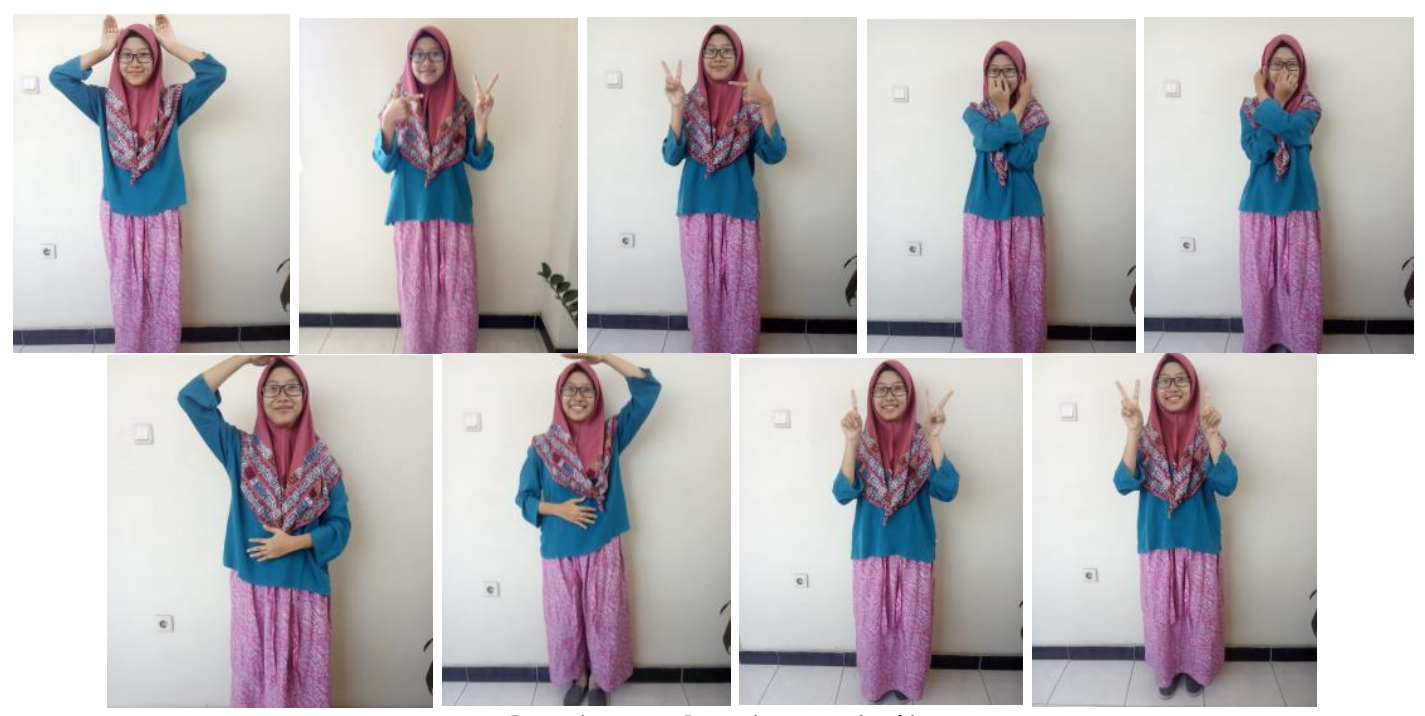

Gambar 3. Gerakan gelatik

\section{Hasil akhir video gerak dan lagu neurokinestetik}

Uji Keefektifan Gerak dan Lagu Neurokinestetik untuk Menumbuhkan Kreativitas Anak Usia Dini. Uji keefektifan ini akan dilakukan setelah mendapatkan validasi dari validator. Berikut adalah hasil uji coba keefektifan gerak dan lagu kepada anak:

\section{Hasil Pencapaian Gerak dan Lagu Menggunakan Video Gelatik}

Hasil uji coba penggunaan video gelatik sebelum dilaksanakan pretes memiliki ratarata tingkat kreativitas sebesar 17,75 poin. Setelah dilaksanakan perlakuan menggunakan video gelatik, setelah dilakukan post test memiliki rata-rata sebesar 30,55 poin. Hasil pretest dan posttest berdasarkan kriteria dapat dilihat berdasarkan Tabel 1.

Tabel 1 Hasil Pencapaian Gerak dan Lagu Menggunakan Video Gelatik

\begin{tabular}{clcccc}
\hline \multirow{2}{*}{ Skor } & \multicolumn{1}{c}{ Kriteria } & \multicolumn{2}{c}{ Pretes } & \multicolumn{2}{c}{ Postes } \\
\hline 4 & $\begin{array}{l}\text { Berkembang Sangat Baik } \\
\text { (BSB) }\end{array}$ & 0 & $0 \%$ & 4 & $20 \%$ \\
3 & $\begin{array}{l}\text { Berkembang Sesuai } \\
\text { Harapan (BSH) }\end{array}$ & 0 & $0 \%$ & 11 & $80 \%$ \\
2 & $\begin{array}{l}\text { Mulai Berkembang (MB) } \\
1\end{array}$ & 8 & $60 \%$ & 0 & $0 \%$ \\
\hline
\end{tabular}

Hasil pengujian menggunakan uji sampel berpasangan (paired sample test) dinyatakan bahwa hasil pengujian keefektifan video gelatik dalam menumbuhkan kreatifitas anak usia dini efektif.

Tabel 2 Hasil Uji Paired Sample Statistics Kelompok 1 Paired Samples Statistics

\begin{tabular}{|c|c|c|c|c|c|}
\hline & & Mean & $\mathrm{N}$ & $\begin{array}{c}\text { Std. } \\
\text { Deviation }\end{array}$ & $\begin{array}{l}\text { Std. Error } \\
\text { Mean }\end{array}$ \\
\hline Pair & Pretest_1 & 15.45 & 15 & 1.943 & .434 \\
\hline 1 & Posttest_1 & 18.65 & 15 & 3.501 & .782 \\
\hline
\end{tabular}


Berdasarkan Tabel 1 didapatkan bahwa nilai rata-rata pretes yang semula 15,45 mengalami perubahan menjadi 18,65, jadi kelompok 1 mengalami peningkatan sebesar 3,20.

\section{Hasil Pencapaian Gerak dan Lagu Menggunakan Video Konvensional}

Sebelum dilaksanakan kegiatan, hasil pencapaian perkembangan dengan media konvensional memiliki nilai rata-rata sebesar 18,55 poin. Setelah dilakukan kegiatan, anakanak kelompok 1 diukur lagi untuk mendapatkan kemampuan akhir. Rata-rata hasil postes anak-anak kelompok 1 sebesar 20,25 poin. Hasil pembelajaran kelompok 1 berdasarkan kriteria dapat dilihat berdasarkan Tabel 3.

Tabel 3 Hasil Pencapaian Gerak dan Lagu Menggunakan Video Konvensional

\begin{tabular}{clcccc}
\hline \multirow{2}{*}{ Skor } & \multicolumn{2}{c}{ Kriteria } & \multicolumn{2}{c}{ Pretes } & \multicolumn{2}{c}{ Postes } \\
& & Jumlah & $\%$ & Jumlah & $\%$ \\
\hline 4 & Berkembang Sangat Baik (BSB) & 0 & $0 \%$ & 0 & $0 \%$ \\
3 & Berkembang Sesuai Harapan (BSH) & 0 & $0 \%$ & 3 & $15 \%$ \\
2 & Mulai Berkembang (MB) & 6 & $75 \%$ & 12 & $85 \%$ \\
1 & Belum Berkembang (BB) & 9 & $25 \%$ & 0 & $0 \%$ \\
\hline
\end{tabular}

Hasil pengujian menggunakan uji sampel berpasangan (paired sample tests) dinyatakan bahwa hasil pengujian antara hasil pretes menuju postes kelompok 2 mengalami peningkatan. Peningkatan yang terjadi pada kelompok 2, lebih kecil dibanding peningkatan pada kelompok 1.

Tabel 4 Hasil Uji Paired Sample Statistics Kelompok 2 Paired Samples Statistics

\begin{tabular}{llrrrr}
\hline & & Mean & N & Std. Deviation & \multicolumn{2}{c}{ Std. Error Mean } \\
\hline Pair 1 & pretest_2 & 18.55 & 15 & 1.926 & .430 \\
& posttest_2 & 20.25 & 15 & 2.149 & .480 \\
\hline
\end{tabular}

Berdasarkan Tabel 4 nilai rata-rata pretes kelompok 2 yang semula 18,55 berubah menjadi 20,22, jadi kelompok 2 mengalami peningkatan sebesar 1,70.

\section{Perbedaan Hasil Pencapaian Gerak dan Lagu Menggunakan Video Gelatik dan Video Konvensional}

Efektifnya kegiatan pembelajaran gerak dan lagu dapat diamati berdasarkan hasil pembelajaran maupun tercapainya tujuan pembelajaran. Hasil pembelajaran dapat dianalisis melalui hasil postes, dikarenakan hasil pretes kelompok 1 dan kelompok 2 memiliki hasil permulaan yang sama. Rata-rata hasil postes anak-anak kelompok 1 sebesar 18,65 poin, dengan besar peningkatan dari pretes menuju postes sebesar 3,20. Sementara itu hasil postes anak-anak kelompok 2 sebesar 20,25 poin, dengan besar peningkatan dari pretes menuju postes sebesar 1,70 poin. Keefektifan video gerak dan lagu dapat dilihat dan dianalisis berdasarkan hasil pengujian melalui output independent sample test pada Tabel 5 . 
Tabel 5 Hasil Uji Independent Sample Test Postes

Independent Samples Test

\begin{tabular}{|c|c|c|c|c|c|c|c|c|}
\hline & & \multicolumn{2}{|c|}{$\begin{array}{l}\text { Levene's Test } \\
\text { for Equality of } \\
\text { Variances }\end{array}$} & \multicolumn{5}{|c|}{ t-test for Equality of Means } \\
\hline & & $\mathrm{F}$ & Sig. & $\mathrm{t}$ & $\mathrm{df}$ & $\begin{array}{l}\text { Sig. (2- } \\
\text { tailed) }\end{array}$ & $\begin{array}{c}\text { Mean } \\
\text { Difference }\end{array}$ & $\begin{array}{l}\text { Std. Error } \\
\text { Difference }\end{array}$ \\
\hline \multirow[t]{2}{*}{ Posttest } & $\begin{array}{l}\text { Equal variances } \\
\text { assumed }\end{array}$ & 3.480 & .067 & 9.863 & 58 & .000 & 7.600 & .77053 \\
\hline & $\begin{array}{l}\text { Equal variances } \\
\text { not assumed }\end{array}$ & & & 9.863 & 52.404 & .000 & 7.600 & .77053 \\
\hline
\end{tabular}

Secara umum, hasil penelitian ini dinyatakan bahwa penggunaan video gerak dan lagu neurokinestetik lebih efektif dalam menumbuhkan kreativitas seni anak usia dini dibandingkan menggunakan media konvensional, dengan kata lain video gerak dan lagu neurokinestetik memberikan pengaruh yang signifikan terhadap kreativitas seni anak usia dini.

\section{SIMPULAN}

Berdasarkan hasil penelitian dan pembahasan yang dilakukan tentang penggunaan video gerak dan lagu neurokinestetik untuk menumbuhkan kreativitas anak usia dini, maka dapat ditarik kesimpulan bahwa hasil pencapaian gerak dan lagu neurokinestetik untuk menumbuhkan kreativitas anak usia dini lebih besar dari pada hasil pencapaian gerak dan lagu neurokinestetik untuk menumbuhkan kreativitas anak usia dini menggunakan video konvensional dibuktikan melalui uji $\mathrm{t}$ Independent bahwa data postes antara kelompok 1 dan kelompok 2 adalah $\mathrm{H}_{0}$ ditolak karena memiliki nilai $t_{\text {hitung }}=9,863$ dengan $t_{\text {tabel }}=-2,048$.

\section{UCAPAN TERIMAKASIH}

Penelitian ini mendapatkan hibah dikti dengan skim penelitian dosen pemula. Penulis mengucapkan terima kasih atas diperolehnya hibah dikti ini untuk memperlancar proses penelitian dengan judul "Gerak dan Lagu Neurokinestetik (GELATIK) untuk Menumbuhkan Kreativitas Seni Anak Usia Dini". Penulis juga menyampaikan ucapan terima kasihnya kepada pengelola jurnal OBSESI yang telah memberikan kesempatan penulis menerbitkan artikel hasil penelitian yang di danai oleh dikti.

\section{DAFTAR PUSTAKA}

Anggraini, Denok Dwi. 2015. Peningkatan Kecerdasan Kinestetik Melalui Kegiatan Bermain Sirkuit Dengan Bola. Jurnal PG-PAUD Trunojoyo. Vol 2, No 1. Hal. 65-75.

Apit, Widayati T. 2012. Meningkatkan Kecerdasan Kinestetik Melalui Metode Bermain Menangkap Bola Kecil Pada Kelompok A TK Pertiwi Luwuk Kabupaten Banggai. Jurnal Teknologi Pendidikan. Vol 1, No 2. Hal. 42-72.

Bustomi, M. Yazid. 2012. Panduan Lengkap PAUD Melejitkan Potensi dan Kecerdasan Anak Usia Dini. Citra Publishing

Diana, dkk. 2013. Penerapan Metode Bernyanyi Dengan Menggunakan Alat Bantu Pembelajaran untuk Meningkatkan Kecerdasan Kinestetik Anak di Kelompok B2 Taman Kanak-kanak Aisyah II Pasar Manna Kabupaten Bengkulu Selatan. Thesis. Fakultas Keguruan dan Ilmu Pendidikan Universitas Bengkulu.

Fleetham, Mike. 2006. Multiple Intellegences In Practice. Great Britain: Network Continuum Education.

Gutawa. 2002. Kecerdasan Spiritual dalam Membentuk Perilaku Anak. Jurnal Ilmiah Anak Usia dini. Vol 02. Hal 32-37. 
Husnul, Ade. 2011. Bergembira Melakukan Senam Irama. Jakarta : PT Wadah Ilmu Jackman, Hilda. 2009. Early Education Curriculum. Delmar: Cengange Learning. Jalal, F. 2002. Pendidikan Anak Usia Dini Pendidikan yang Mendasar. Jurnal Ilmiah Anak Usia Dini. Vol 03. Hal 4-8

Khasanah, Imroatun. 2016. Meningkatkan Kecerdasan Kinestetik Anak Melalui Tari Tradisional Angguk di TK Melati II Glagah. Jurnal Pendidikan Anak Usia Dini, Edisi 3. Hal, 292-300.

Lastari. A. A, Gading. I. K, A. P. A. 2016. Penerapann Pembelajaran Gerak Dan Lagu Berbantuann Audiovisual Untuk Meningkatkan Kecerdasan Kinestetik Pada Anak Kelompok. E-Journal Pendidikan Anak Usia Dini. Vol 4 No 2.

Lwin, May, Khoo, Adam, Lyen, Kenneth, \& Sim, Caroline. 2008. Cara Mengembangkan Berbagai Komponen Kecerdasan (How To Multiply Your Child's Intelligence). Yogyakarta: PT Indeks

Majidah, dkk. 2018. Upaya Meningkatkan Kecerdasan Kinestetik Anak Usia Dini Melalui Kegiatan Menari Pada Kelompok B di RA Al-Ikhlas Medan. Jurnal Raudhah. Vol 6, No 1. Hal 1-7.

Meitarini, Loveita. 2019. Peningkatan Kecerdasan Melalui Tari Kreatif untuk Anak Usia 5-6 Tahun di Taman Kanak-kanak Assaid Larangan. Jurnal Instruksional. Vol 1, No 1. Hal. 3242.

Muhajir. 2007. Pendidikan Jasmani Olahraga dan Kesehatan. Bandung: Erlangga.

Munawaroh, L \& Khotimah, N. 2018. Penerapan Kegiatan Tari Kreasi Dalam Kemampuan Kinestetik Anak Kelompok B TK Aisyiyah Bustanul Athfal Kalijaten Taman Sidoarjo. Jurnal PAUD Teratai. Vol 7, No 1. Hal 1-10.

Nurliana, Syarifah. 2016. Strategi Guru Dalam Mengembangkan Kecerdasan Kinestetik Pada Anak Usia 5-6 Tahun Di Taman Kanak-Kanak Bina Sari Kecamatan Pontianak Kota. Skripsi. Universitas Tanjungpura.

Purwanti, Sri. 2014. Peningkatan Kecerdasan Kinestetik Anak Melalui Kegiatan Gerak Dan Lagu Kelompok B Di TK Pertiwi Ceporan I Gantiwarno Klaten Tahun Ajaran 2013/2014. Skripsi thesis, Universitas Muhammadiyah Surakarta.

Rasyid, Fathur. (2010). Cerdaskan Anakmu Dengan Musik. Jogjakarta: Diva Press.

Respati R dan Nur L. 2018. Gerak dan Lagu Sebagai Model Stimulasi Pengembangan Kecerdasan Kinestetik Anak Usia Dini. Jurnal Pendidikan Usia Dini. Vol 12, No 2. Hal. 321-330.

Samsudin. 2008. Pembelajaran Motorik Di Taman Kanak Kanak. Jakarta: Litera.

Saputra, Yudha M., \& Rudyanto. (2005). Pembelajaran Kooperatif Untuk Meningkatkan Keterampilan Anak TK. Jakarta: Departemen Pendidikan Nasional

Sari, Mulya. 2014. Peningkatan Kecerdasan Kinestetik Melalui Kegiatan Bermain Air. Jurnal Pendidikan Usia Dini. Vol 8, No 1. Hal. 373-382.

Sudjono, Elisabeth T. K., dan Kusumastuti, Eny. 2017. Proses Pembelajaran Gerak dan Lagu yang Kreatif Berdasarkan Kurikulum 2013 di TK Miryam Semarang. Jurnal Seni Tari. Vol 6, No 2. Hal. 1-9.

Sujiono, Yuliani Nurani. 2010. Bermain Kreatif Berbasis Kecerdasan Jamak. Jakarta: PT. Indeks.

Susanto. 2012. Perkembangan Anak Usia Dini. Jakarta: Kencana Prenada Media Group.

Triana, Dinny D. 2012. Kinesthetic Assessment of Dance Arts. Jurnal Evaluasi Pendidikan. Vol 3, No 1. Hal 42-58.

Umami, dkk. 2016. Peningkatan Kecerdasan Kinestetik Anak Melalui Permainan Estafet. Jurnal Ilmiah Potensia. Vol 1, No 1. Hal 15-20.

Widhianawati, Nana. 2011. Pengaruh pembelajaran gerak dan lagu dalam meningkatkan kecerdasan musikal dan kecerdasan kinestetik anak usia dini. Edisi Khusus No. 2, Agustus 2011.

Yustisia, N. 2013.75 Rahasia anak Cerdas. Jogjakarta: Kata Hati 